\title{
Antibacterial serrulatane diterpenes from the Australian native plant
}

\section{Eremophila microtheca}

Emma C. Barnes, ${ }^{\mathrm{a}}$ Angela M. Kavanagh, ${ }^{\mathrm{b}}$ Soumya Ramu, ${ }^{\mathrm{b}}$ Mark A. Blaskovich, ${ }^{\mathrm{b}}$ Matthew A. Cooper, ${ }^{\mathrm{b}}$ and Rohan A. Davis ${ }^{\mathrm{a}}{ }^{\text {* }}$

${ }^{a}$ Eskitis Institute, Griffith University, Nathan, QLD, 4111, Australia.

${ }^{\mathrm{b}}$ Institute for Molecular Bioscience, University of Queensland, St Lucia, QLD, 4072, Australia.

\section{Abstract}

Chemical investigations of the aerial parts of the Australian plant Eremophila microtheca resulted in the isolation of three new serrulatane diterpenoids, 3-acetoxy7,8-dihydroxyserrulat-14-en-19-oic acid (1), 3,7,8-trihydroxyserrulat-14-en-19-oic acid (2), and 3,19-diacetoxy-8-hydroxyserrulat-14-ene (3) as well as the previously reported compounds verbascoside (4) and jaceosidin (5). Acetylation and methylation of the major serrulatane diterpenoid (2) afforded 3,8-diacetoxy-7-hydroxyserrulat-14en-19-oic acid (6) and 3,7,8-trihydroxyserrulat-14-en-methyl-19-benzoate (7), respectively. The antibacterial activity of 1-7 was assessed against a panel of Grampositive and Gram-negative bacterial isolates. All the serrulatane compounds exhibited moderate activity against Streptococcus pyogenes (ATCC 12344) with minimum inhibitory concentrations (MICs) ranging from 64-128 $\mu \mathrm{g} / \mathrm{mL}$. Serrulatane 1 demonstrated activity against all Gram-positive bacterial strains (MICs

\footnotetext{
* Corresponding author. Address: Eskitis Institute, Griffith University, Nathan, QLD, 4111, Australia. Tel.: +61 73735 6043; fax: +61 73735 6001. E-mail address: r.davis@ griffith.edu.au (R.A. Davis).
} 
$64-128 \mu \mathrm{g} / \mathrm{mL}$ ) except for Enterococcus faecalis and Enterococcus faecium. This is the first report of natural products from Eremophila microtheca.

\section{Keywords}

Eremophila microtheca; Myoporaceae; Antibacterial; Serrulatane; Diterpenoid

\section{Introduction}

While the Australian endemic genus Eremophila (family Myoporaceae) has been a source of $>100$ structurally diverse compounds, mostly within the terpenoid structure class, a large number of the 215 species identified to date remain chemically under-investigated (Chinnock, 2007; Dictionary of Natural Products, 2012; Ghisalberti, 1994a; Ghisalberti, 1994b). Eremophila plants grow within the arid and semi-arid regions of Australia, and a number of these species are recorded as having been used by Australian Aboriginal people to treat a range of ailments such as colds, wounds, and scabies (Ghisalberti, 1994a; Latz, 1995; Low, 1990). A number of bioactivities have been reported for Eremophila extracts or isolated natural products, including antibacterial (Liu et al., 2006; Ndi et al., 2007a; Ndi et al., 2007b; Ndi et al., 2007c; Palombo and Semple, 2001, 2002; Smith et al., 2007; Wilkinson and Cavanagh, 2005), antiviral (Semple et al., 1998), anti-inflammatory (Liu et al., 2006), anti-malarial (Barnes et al., 2012), and cytotoxic activities (Beattie, 2009; Beattie et al., 2011). Furthermore, Eremophila extracts and/or natural products have been studied for their cardioactivity (Pennacchio et al., 1995; Pennacchio et al., 2005; Pennacchio et al., 1996, 1997) and have been investigated as potential treatments for 
neurological disorders such as migraine (Grice et al., 2003; Rogers et al., 2002; Rogers et al., 2000, 2001).

Literature searches on the Eremophila samples contained within the Eskitis Institute's Nature Bank biota library (Nature Bank, 2011) identified a number of under-investigated species, including Eremophila microtheca (F. Muell. ex Benth.) (Dictionary of Natural Products, 2012; SciFinder, 2012). Only one reference could be found on E. microtheca, in which an extract of this species was included in a study of the antimicrobial activity of 72 Eremophila plants (Ndi et al., 2007a). No reports were found of natural products that had been isolated from E. microtheca, indicating that this plant had the potential to yield new and/or bioactive chemistry. Due to our continuing interest in the chemistry of Eremophila species (Barnes et al., 2011; Barnes et al., 2012) we thus prioritised E. microtheca for chemical investigation.

E. microtheca grows as an erect shrub up to $1.5 \mathrm{~m}$ tall with lilac flowers (Chinnock, 2007). The name microtheca comes from the Greek language, with 'micro' meaning small, and 'theca' case or container, which refers to the small nature of the fruit of this particular plant. This species is relatively rare in the wild, being found in just a few localities in Western Australia (Chinnock, 2007). However, this plant is becoming a common addition in many nurseries within Australia due to its attractive flowers and drought tolerance. This species also possesses a distinctive aroma that some find offensive. Chinnock reported that the odour of the foliage can be discerned from some distance, and that one large wild population of E. microtheca was discovered after the searchers followed the odour to the source (Chinnock, 2007).

Herein we report the isolation and structure elucidation of three new serrulatanes from E. microtheca. These natural products as well as two semi-synthetic derivatives were also examined for their anti-bacterial activity. 


\section{Results and discussion}

The air-dried aerial parts of E. microtheca were extracted with sequential washes of $\mathrm{CH}_{2} \mathrm{Cl}_{2}$ and $\mathrm{CH}_{3} \mathrm{OH}$. Both extracts were combined and subsequently fractionated by semi-preparative $\mathrm{HPLC}\left(\mathrm{C}_{18}\right.$-bonded silica, $\left.\mathrm{H}_{2} \mathrm{O} / \mathrm{CH}_{3} \mathrm{OH}\right)$. This afforded the new serrulatanes: 3-acetoxy-7,8-dihydroxyserrulat-14-en-19-oic acid (1, $66 \mathrm{mg}, 0.638 \%$ dry wt); 3,7,8-trihydroxyserrulat-14-en-19-oic acid (2, $453 \mathrm{mg}$, 4.355\% dry wt); and 3,19-diacetoxy-8-hydroxyserrulat-14-ene (3, $54 \mathrm{mg}, 0.519 \%$ dry wt) and the previously reported compound verbascoside $(4,44 \mathrm{mg}, 0.418 \%$ dry wt) (Aligiannis et al., 2003; Andary et al., 1982). One semi-pure fraction from the HPLC work was further purified by size exclusion chromatography (Sephadex LH-20, $\left.\mathrm{CH}_{2} \mathrm{Cl}_{2}: \mathrm{CH}_{3} \mathrm{OH}\right)$ to afford the known flavonoid jaceosidin $(\mathbf{5}, 9 \mathrm{mg}, 0.088 \%$ dry wt) (ApSimon et al., 1963; Nakasugi et al., 2000).

Compound 1 was isolated as an optically active brown gum and assigned a molecular formula of $\mathrm{C}_{22} \mathrm{H}_{30} \mathrm{O}_{6}$ (eight degrees of unsaturation) on the basis of NMR (Tables 1 and 2) and HRESIMS data. The ${ }^{1} \mathrm{H}$ NMR spectrum of $\mathbf{1}$ indicated the presence of five methyl groups $\left(\delta_{\mathrm{H}} 0.47,1.20,1.56,1.65\right.$ and 2.00$)$, one -OCHRmoiety $\left(\delta_{\mathrm{H}} 5.19\right)$, and two olefinic protons $\left(\delta_{\mathrm{H}} 5.10\right.$ and 6.96) and also contained several upfield signals that integrated for eight protons. The ${ }^{13} \mathrm{C}$ NMR and edited HSQC spectra of 1 indicated a total of 22 carbons (Table 2), including five methyls $\left(\delta_{\mathrm{C}} 17.5,18.8,21.0,21.5,25.5\right)$, two carbonyls $\left(\delta_{\mathrm{C}} 169.8\right.$ and 172.3$)$, three methylenes $\left(\delta_{\mathrm{C}} 25.4,31.4,37.4\right), \operatorname{six}^{2} \mathrm{sp}^{2}$ quaternary carbons $\left(\delta_{\mathrm{C}} 110.3,126.6,130.8,134.7,142.4\right.$ 147.7), two $\mathrm{sp}^{2}$ methines $\left(\delta_{\mathrm{C}} 119.8\right.$ and 124.3$)$, and four $\mathrm{sp}^{3}$ methines $\left(\delta_{\mathrm{C}} 28.0,31.2\right.$, $44.5,69.6)$. 
The

extended

spin

system

(R) $\mathrm{CH}\left(\mathrm{CH}_{3}\right) \mathrm{CH}_{2} \mathrm{CH}(\mathrm{OR}) \mathrm{CH}(\mathrm{R}) \mathrm{CH}\left(\mathrm{CH}_{3}\right) \mathrm{CH}_{2} \mathrm{CH}_{2} \mathrm{CH}=\mathrm{C}\left(\mathrm{CH}_{3}\right)_{2}$ was readily established following interpretation of the COSY data for $\mathbf{1}$ and was supported by key HMBC correlations (Figure 1). For example, the methyl group at $\mathrm{H}-20\left(\delta_{\mathrm{H}} 1.20\right)$ showed HMBC correlations to C-1 $\left(\delta_{\mathrm{C}} 28.0\right), \mathrm{C}-2\left(\delta_{\mathrm{C}} 31.4\right)$, and C-9 $\left(\delta_{\mathrm{C}} 134.7\right)$. HMBC correlations from $\delta_{\mathrm{H}} 1.95(\mathrm{H}-13)$ to $\mathrm{C}-14\left(\delta_{\mathrm{C}} 124.3\right)$ and $\mathrm{C}-15\left(\delta_{\mathrm{C}} 130.8\right)$ and from $\delta_{\mathrm{H}} 5.10(\mathrm{H}-14)$ to $\mathrm{C}-16\left(\delta_{\mathrm{C}} 25.5\right)$ and $\mathrm{C}-17\left(\delta_{\mathrm{C}} 17.5\right)$ confirmed that the side chain terminated with a di-methylated olefin moiety. Substructure searching of this spin system in conjunction with the taxonomic genus in DNP (Dictionary of Natural Products, 2012) indicated that $\mathbf{1}$ possessed a serrulatane skeleton.

The remainder of structure $\mathbf{1}$ was assembled as follows. An acetoxy group was attached to $\mathrm{C}-3$ on the basis of strong HMBC correlations from both the downfield proton at $\delta_{\mathrm{H}} 5.19(\mathrm{H}-3)$ and the methyl group at $\delta_{\mathrm{H}} 2.00(\mathrm{H}-22)$ to the carbonyl at $\delta_{\mathrm{C}}$ 169.8 (C-21) (Ndi et al., 2007c). H-4 showed HMBC correlations to carbons resonating at $\delta_{\mathrm{C}} 119.8(\mathrm{C}-5), \delta_{\mathrm{C}} 134.7(\mathrm{C}-9)$, and $\delta_{\mathrm{C}} 126.6(\mathrm{C}-10)$, indicating that it was adjacent to an aromatic system. $\mathrm{H}-1\left(\delta_{\mathrm{H}} 3.26\right)$ also showed HMBC correlations to C-9 and C-10, allowing a cyclohexene (ring A) to be formed. The proton at $\delta_{\mathrm{H}} 6.96$ was attached to a carbon at $\delta_{\mathrm{C}} 119.8$ on the basis of HSQC data, and HMBC correlations from this $\mathrm{sp}^{2}$ methine to $\mathrm{C}-4$ and $\mathrm{C}-9$ of ring A allowed it to be assigned to $\mathrm{H}-5$.

At this point a subunit of $\mathrm{C}_{4} \mathrm{O}_{4} \mathrm{H}_{3}$ remained to be elucidated. The four remaining carbons included one carbonyl $\left(\delta_{\mathrm{C}} 172.3\right)$ and three aromatic quaternary $\left(\delta_{\mathrm{C}}\right.$ $110.3,147.7$ and 142.4$)$ signals. The proton at $\mathrm{H}-5\left(\delta_{\mathrm{H}} 6.96\right)$ possessed a HMBC correlation to the carbon at $\delta_{\mathrm{C}} 147.7$, placing it at $\mathrm{C}-7$, while $\mathrm{H}-1\left(\delta_{\mathrm{H}} 3.26\right)$ demonstrated a strong three-bond $\mathrm{HMBC}$ correlation to $\delta_{\mathrm{C}} 142.4$, positioning it at C- 
8. This allowed the formation of the benzenoid system, ring B (Figure 1). The proton at $\mathrm{H}-5$ also showed a $\mathrm{HMBC}$ correlation to the carbon at $\delta_{\mathrm{C}} 172.3$, hence a carbonyl group was placed at C-6 $\left(\delta_{\mathrm{C}} 110.3\right)$. This left the equivalent of three $-\mathrm{OH}$ moieties to position within the structure, suggesting a carboxylic acid and two hydroxy groups at C-6, C-7 and C-8, respectively. While neither the phenolic or carboxylic acid protons were identified in the ${ }^{1} \mathrm{H}$ NMR spectrum of $\mathbf{1}$, the NMR data supported the assigned substitution pattern of ring B after comparison with literature data (Forster et al., 1986). Furthermore, the IR spectrum of 1 showed strong absorptions at 3262, 1667, and $1731 \mathrm{~cm}^{-1}$, which confirmed the presence of phenolic, aromatic carboxylic acid and ester moieties, respectively (Pretsch et al., 2009). Thus the planar structure of $\mathbf{1}$ was assigned.

Of note is the shielding effect seen for the secondary methyl group at H-18. It has been reported that when a secondary hydroxy group is located at C-3, the signal for $\mathrm{H}-18$ is shifted significantly upfield $\left(\delta_{\mathrm{H}} \sim 0.60\right.$ in $\mathrm{CDCl}_{3}, \delta_{\mathrm{H}} \sim 0.30$ in DMSO- $\left.d_{6}\right)$ (Liu et al., 2006; Syah and Ghisalberti, 1997; Tippett and Massy-Westropp, 1993) compared to when the hydroxy group is not present $\left(\delta_{\mathrm{H}} \sim 1.00\right.$ in both $\mathrm{CDCl}_{3}$ and DMSO- $d_{6}$ ) (Liu et al., 2006; Ndi et al., 2007b; Ndi et al., 2007c; Syah and Ghisalberti, 1997; Tippett and Massy-Westropp, 1993). The acetoxy group at H-3 in $\mathbf{1}$ has a similar effect to a hydroxy moiety, with the chemical shift of $\mathrm{H}-18$ being $\delta_{\mathrm{H}} 0.47$ in $\mathbf{1}$.

The relative configuration of $\mathbf{1}$ was established through analysis of the ROESY and ${ }^{1} \mathrm{H}-{ }^{1} \mathrm{H}$ coupling constant data and with comparison to literature values. ROESY correlations between $\mathrm{H}-4 / \mathrm{H}-3, \mathrm{H}-4 / \mathrm{H}-2 \beta, \mathrm{H}-3 / \mathrm{H}-2 \beta$, and $\mathrm{H}-3 / \mathrm{H}-20$ placed these protons on the same face of ring A. The small ${ }^{1} \mathrm{H}-{ }^{1} \mathrm{H}$ coupling constants between $\mathrm{H}-4 / \mathrm{H}-3\left(J_{3,4}=3.6 \mathrm{~Hz}\right)$ and $\mathrm{H}-3 / \mathrm{H}-2 \beta\left(J_{3,2 \beta}=4.2 \mathrm{~Hz}\right)$ supported the $c i s$ orientation of these protons. The relative configuration of the cyclohexene system 
present in $\mathbf{1}$ is consistent with that reported for the majority of serrulatanes described in the literature. Only one serrulatane, compound 11, isolated from E. phyllopoda has been found to have the opposite configuration at C-1 (Syah and Ghisalberti, 1997). The relative configuration of the related natural products $\mathbf{8}$ and $\mathbf{9}$ was established by X-ray crystallographic analysis (Croft et al., 1981; Croft et al., 1977), which allowed for the assignment of stereochemistry at $\mathrm{C}-11$. The majority of previous studies on serrulatanes have assigned the C-11 relative configuration to be identical to that of $\mathbf{8}$ and $\mathbf{9}$, on the basis of similar NMR spectroscopic data and biosynthetic grounds (Liu et al., 2006; Ndi et al., 2007b; Ndi et al., 2007c). Comparison of the NMR data of 1 with related serrulatanes showed a high degree of similarity for ${ }^{1} \mathrm{H}$ and ${ }^{13} \mathrm{C}$ chemical shifts about $\mathrm{C}-11$, thus the relative configuration was determined to be the same as that of previously reported metabolites (Liu et al., 2006; Syah and Ghisalberti, 1997; Tippett and Massy-Westropp, 1993). Consequently the chemical structure of $\mathbf{1}$ was assigned as 3-acetoxy-7,8-dihydroxyserrulat-14-en-19-oic acid.

Compound 2 was determined to have a molecular formula of $\mathrm{C}_{20} \mathrm{H}_{28} \mathrm{O}_{5}$ based on the sodiated pseudomolecular ion at $\mathrm{m} / \mathrm{z} 371.1844$ in the (+)-HRESIMS (calcd. 371.1829), which equated to seven degrees of unsaturation. The molecular weight difference of 42 Da between 1 and $\mathbf{2}$ suggested that $\mathbf{2}$ contained a hydroxy rather than an acetoxy moiety. Comparison of the NMR data of compounds $\mathbf{1}$ and $\mathbf{2}$ (Tables 1 and 2) showed they had almost identical ${ }^{1} \mathrm{H}$ and ${ }^{13} \mathrm{C}$ chemical shifts for both rings and the alkene side chain. The only major differences were that 2 lacked the ${ }^{1} \mathrm{H}$ and ${ }^{13} \mathrm{C}$ signals of an acetoxy group, and that the H-3 and C-3 resonances of $2\left(\delta_{\mathrm{H}} 4.05\right.$ and $\delta_{\mathrm{C}}$ 64.9) resonated further upfield than that of $1\left(\delta_{\mathrm{H}} 5.19\right.$ and $\left.\delta_{\mathrm{C}} 69.6\right)$. These data indicated that $\mathbf{2}$ was the de-acetyl derivative of $\mathbf{1}$. Furthermore, the chemical shift of $\mathrm{H}-18\left(\delta_{\mathrm{H}} 0.36\right)$ was in agreement with literature values reported when a hydroxy 
group is located at C-3 in the pseudo-equatorial position $\left(\delta_{\mathrm{H}} \sim 0.30\right.$ in DMSO- $\left.d_{6}\right)$ (Liu et al., 2006; Ndi et al., 2007b; Ndi et al., 2007c; Syah and Ghisalberti, 1997; Tippett and Massy-Westropp, 1993). While the phenolic protons were not observed in the ${ }^{1} \mathrm{H}$ NMR spectrum of $\mathbf{1}$, a downfield hydroxy signal $\left(\delta_{\mathrm{H}} 8.60\right)$ was detected for 2 and attached to C-8 based on HMBC correlations from this resonance to C-7, C-8, and C9. The ROESY and ${ }^{1} \mathrm{H}^{-1} \mathrm{H}$ coupling constant data for $\mathbf{2}$ were essentially identical to that of $\mathbf{1}$, hence the chemical structure of $\mathbf{2}$ was assigned to 3,7,8-trihydroxyserrulat14-en-19-oic acid.

The third new serrulatane to be identified, compound $\mathbf{3}$, also displayed a very similar ${ }^{1} \mathrm{H}$ NMR spectrum to that of natural product $\mathbf{1}$ (Table 1 ). The only observed differences were that $\mathbf{3}$ possessed an additional aromatic proton resonance $\left(\delta_{\mathrm{H}} 6.64\right)$, an extra methyl group $\left(\delta_{\mathrm{H}} 2.03\right)$, and an $-\mathrm{OCH}_{2}-$ moiety $\left(\delta_{\mathrm{H}} 4.92\right)$. The ${ }^{13} \mathrm{C} \mathrm{NMR}$ spectrum of $\mathbf{3}$ (Table 2) was similar to that of $\mathbf{1}$ in that it contained two carbonyl signals $\left(\delta_{\mathrm{C}} 170.1\right.$ and 169.8$)$, however, it possessed an additional oxygenated carbon signal $\left(\delta_{\mathrm{C}} 65.4\right)$ and lacked one of the phenolic carbons of 1 . The 2D NMR data of 3 indicated that it differed from $\mathbf{1}$ in the substitution of the benzene ring (ring B). It was determined that the hydroxy at C-7 in $\mathbf{1}$ had been replaced by a hydrogen $\left(\delta_{\mathrm{H}} 6.64\right)$ in 3 as indicated by HMBC correlations from this proton to C-5 $\left(\delta_{\mathrm{C}} 119.9\right)$ and C-9 $\left(\delta_{\mathrm{C}}\right.$ 127.4). H-5 and H-7 shared a HMBC correlation to $\delta_{\mathrm{C}} 65.4$ (C-19), which allowed the $-\mathrm{OCH}_{2}-$ moiety to be substituted at C-6. The methylene protons at $\mathrm{H}-19\left(\delta_{\mathrm{H}} 4.92\right)$ showed a HMBC correlation to the carbonyl carbon at $\delta_{\mathrm{C}} 170.1$, as did the methyl group at $\delta_{\mathrm{H}} 2.03$, which established an acetoxy moiety at C-19.

The molecular formula obtained for 3 of $\mathrm{C}_{24} \mathrm{H}_{34} \mathrm{O}_{5}$ (eight degrees of unsaturation) from the HRESIMS data was in agreement with the NMR data. After analyses of the ROESY spectrum and ${ }^{1} \mathrm{H}-{ }^{1} \mathrm{H}$ coupling constants the relative 
configuration of $\mathbf{3}$ was found to be the same as that of $\mathbf{1}$ and $\mathbf{2}$. The chemical structure of $\mathbf{3}$ was therefore determined to be 3,19-diacetoxy-8-hydroxyserrulat-14-ene. Natural product $\mathbf{3}$ is a positional isomer of serrulatane $\mathbf{1 0}$, which was isolated from E. neglecta (Ndi et al., 2007c).

The previously reported natural products verbascoside (Aligiannis et al., 2003; Andary et al., 1982) and jaceosidin (ApSimon et al., 1963; Nakasugi et al., 2000) were assigned to compounds 4 and $\mathbf{5}$, respectively, after MS and 1D/2D NMR spectroscopic data analyses and comparison with literature values. Verbascoside has reportedly been found in a number of Eremophila spp. (Dictionary of Natural Products, 2012). This is the first report of jaceosidin (5) having been isolated from an Eremophila sp..

Literature reports have identified a number of serrulatanes that demonstrate selective antimicrobial activity towards Gram-positive bacteria, and just one has been shown to inhibit a Gram-negative bacterial strain (Anakok et al., 2011; Liu et al., 2006; Ndi et al., 2007b; Ndi et al., 2007c; Smith et al., 2007). During the antibacterial screening of 72 Eremophila plants, Ndi et al. found that an extract of E. microtheca inhibited Staphylococcus aureus, Streptococcus pyogenes, and Streptococcus pneumonia with MICs ranging from 31-125 $\mu \mathrm{g} / \mathrm{mL}$ (Ndi et al., 2007a). On account of this data, we decided to screen our compounds against a panel of bacterial strains.

As serrulatane 2 had been isolated in such large quantities $(453 \mathrm{mg}$ ), we decided that prior to antimicrobial screening a number of simple analogues would be generated in order to facilitate structure activity relationships for this particular diterpenoid class. In parallel, 2 was acetylated using $\mathrm{Ac}_{2} \mathrm{O}$ and dry pyridine (Davis et al., 1999) and methylated using TMS-diazomethane in $\mathrm{CH}_{3} \mathrm{OH} / \mathrm{CH}_{2} \mathrm{Cl}_{2}$ (Garfunkle et al., 2009). Both reaction crudes were purified using semi-preparative HPLC $\left(\mathrm{C}_{18^{-}}\right.$ 
bonded silica, $\left.\mathrm{CH}_{3} \mathrm{OH} / \mathrm{H}_{2} \mathrm{O}\right)$. The acetylation reaction afforded compound $\mathbf{6}(3,8-$ diacetoxy-7-hydroxyserrulat-14-en-19-oic acid, $16 \mathrm{mg}$, 53\% yield), while the methylation procedure resulted in derivative 7 (3,7,8-trihydroxyserrulat-14-enmethyl-19-benzoate, $9 \mathrm{mg}, 35 \%$ yield). The 1D/2D NMR spectroscopic and HRESIMS data obtained for each of these compounds confirmed their structures.

Compounds 1-7 were screened against a panel of nine Gram-positive and one Gram-negative bacterial strains (Table 3). The majority of the compounds 1-7 were found to be inactive at the highest concentration tested $(128 \mu \mathrm{g} / \mathrm{mL})$ against most bacteria, though all the serrulatane compounds were found to be moderately active (MICs $64-128 \mu \mathrm{g} / \mathrm{mL}$ ) against $S$. pyogenes. Natural product 1 demonstrated activity at $128 \mu \mathrm{g} / \mathrm{mL}$ against all bacterial strains except for Enterococcus faecalis and Enterococcus faecium. Jaceosidin (5) had the greatest potency (MICs $16-32 \mu \mathrm{g} / \mathrm{mL}$ ) against most S. aureus isolates, while verbascoside (4) was inactive against all bacterial strains.

Ndi et al. found that two serrulatanes (12 and 13) from E. duttoni possessed antibacterial activity against $S$. aureus (ATCC 29213, MIC 7.8-15.6 $\mu \mathrm{g} / \mathrm{mL}$ ), however, they were shown to be unstable upon separation. The acetylation of the hydroxy groups of these serrulatanes generated stable compounds that could be separated (14 and 15), however, this also resulted in a loss of antibacterial activity. This indicated that phenolic groups are required in order for these natural products to elicit an antibacterial effect, but such groups may also cause the instability of these compounds as diphenols can be easily oxidised to form quinones (Ndi et al., 2012). In our study, the acetylated compound $\mathbf{6}$ was active against S. aureus (ATCC 43300) and S. pyogenes (MICs $128 \mu \mathrm{g} / \mathrm{mL}$ and $64 \mu \mathrm{g} / \mathrm{mL}$, respectively) while natural product 2 was only active against $S$. pyogenes (MIC $128 \mu \mathrm{g} / \mathrm{mL}$ ). As only partial acetylation 
was achieved for $\mathbf{6}$, it may be that this has stabilised the compound while leaving one of the phenolic groups free for interaction with the target. Ndi et al. also found that serrulatane 10, which is an isomer of $\mathbf{3}$, was inactive ( $\mathrm{MIC}>250 \mu \mathrm{g} / \mathrm{mL}$ ) against strains of S. aureus, S. pyogenes, and S. pneumonia (Ndi et al., 2007c), while in this investigation 3 was active against $S$. pyogenes (MIC $128 \mu \mathrm{g} / \mathrm{mL}$ ).

\section{Conclusions}

Three new members of the serrulatane structure class and the known compounds verbascoside and jaceosidin were isolated from the aerial parts of $E$. microtheca. Acetylated and methylated derivatives of one of the new serrulatanes were generated and the antibacterial activity of all the natural products and semisynthetic derivatives was assessed against a panel of Gram-positive and Gramnegative bacterial strains. Jaceosidin was shown to possess the most potent antibacterial activity with MIC values of $16-32 \mu \mathrm{g} / \mathrm{mL}$ against most $S$. aureus strains, including daptomycin, glycopeptide, and methicillin resistant strains. This is the first report of natural products from E. microtheca.

\section{Experimental}

\subsection{General experimental procedures}

Optical rotations were recorded on a Jasco P-1020 polarimeter. IR and UV spectra were recorded on a Bruker Tensor 27 spectrophotometer and a Jasco V-650 UV/Vis spectrophotometer, respectively. NMR spectra were recorded at $30{ }^{\circ} \mathrm{C}$ on either a Varian $500 \mathrm{MHz}$ or $600 \mathrm{MHz}$ Unity INOVA spectrometer. The latter 
spectrometer was equipped with a triple resonance cold probe. The ${ }^{1} \mathrm{H}$ and ${ }^{13} \mathrm{C}$ chemical shifts were referenced to the solvent peaks for DMSO- $d_{6}$ at $\delta_{\mathrm{H}} 2.49$ and $\delta_{\mathrm{C}}$ 39.5. LRESIMS were recorded on a Mariner Time-of-Flight spectrometer equipped with a Gilson 215 eight probe injector or a Waters ZQ mass spectrometer. HRESIMS were recorded on a Bruker Apex III 4.7 Tesla Fourier transform ion cyclotron resonance mass spectrometer or a Bruker micrOTOF-Q instrument with a Bruker ESI source. An Edwards Instrument company Bio-line orbital shaker was used for plant extractions. A Waters 600 pump equipped with a Waters 966 PDA detector and a Waters 717 Plus Autosampler connected to a Gilson FC204 fraction collector were used for semi-preparative separations. Alltech $\mathrm{C}_{18}$ bonded silica, 35-75 $\mu \mathrm{m}, 150 \AA$ and Alltech stainless steel guard cartridges $(10 \times 30 \mathrm{~mm})$ were used for preadsorption work. A ThermoElectron $\mathrm{C}_{18}$ Betasil $5 \mu \mathrm{m} 143 \AA(21.2 \times 150 \mathrm{~mm})$ column was used for semi-preparative HPLC separations. Size exclusion chromatography was undertaken using a LH-20 Sephadex column $(35 \times 310 \mathrm{~mm})$. All solvents used for chromatography, $[\alpha]_{D}$, UV, and MS were Lab Scan HPLC grade, and the $\mathrm{H}_{2} \mathrm{O}$ was Millipore Milli-Q PF filtered. All synthetic reagents were obtained from SigmaAldrich and used without further purification.

\subsection{Plant material}

E. microtheca was cultivated and identified by J. Glazebrook at Logan Village, Queensland, Australia and the aerial parts harvested in March 2011. A voucher specimen (RAD039) has been deposited at the Eskitis Institute, Griffith University, Brisbane, Australia. 


\subsection{Extraction and isolation}

The air-dried aerial parts of E. microtheca $(10.4 \mathrm{~g})$ were poured into a conical flask $(1 \mathrm{~L})$ then sequentially extracted with $\mathrm{CH}_{2} \mathrm{Cl}_{2}(250 \mathrm{~mL} \times 4)$ and $\mathrm{CH}_{3} \mathrm{OH}(250$ $\mathrm{mL} \times 4$ ) while being shaken at $150 \mathrm{rpm}$. All $\mathrm{CH}_{2} \mathrm{Cl}_{2}$ and $\mathrm{CH}_{3} \mathrm{OH}$ extractions were combined and dried under reduced pressure to yield a brown gum (3.26 g). This crude extract was divided into ten equal portions, and each portion pre-adsorbed to $\mathrm{C}_{18^{-}}$ bonded silica $(\sim 1 \mathrm{~g})$, packed into a guard cartridge then attached to a semipreparative $\mathrm{C}_{18}$-bonded silica HPLC column. Isocratic conditions of $\mathrm{H}_{2} \mathrm{O} / \mathrm{CH}_{3} \mathrm{OH}$ (9:1) were held for $10 \mathrm{~min}$, followed by a linear gradient to $\mathrm{CH}_{3} \mathrm{OH}$ over $40 \mathrm{~min}$, then isocratic conditions of $\mathrm{CH}_{3} \mathrm{OH}$ for $10 \mathrm{~min}$, all at a flow rate of $9 \mathrm{~mL} / \mathrm{min}$. Sixty fractions $(60 \times 1 \mathrm{~min})$ were collected for each run. From the ten HPLC separations,

similar fractions were combined then analysed by (+)-LRESIMS and ${ }^{1} \mathrm{H}$ NMR spectroscopy. Fraction 30 contained verbascoside (4, $44 \mathrm{mg}, 0.418 \%$ dry wt), fractions 41-42 contained semi-pure jaceosidin (5), fractions 46-47 afforded 3,7,8trihydroxyserrulat-14-en-19-oic acid (2, $453 \mathrm{mg}, 4.355 \%$ dry wt), fraction 51 was shown to contain 3-acetoxy-7,8-dihydroxyserrulat-14-en-19-oic acid (1, $66 \mathrm{mg}$, $0.638 \%$ dry wt), and fraction 52 yielded 3,19-diacetoxy-8-hydroxyserrulat-14-ene (3, $54 \mathrm{mg}, 0.519 \%$ dry wt). Fractions 41 and 42 were further purified on a LH-20 Sephadex size exclusion column using $\mathrm{CH}_{2} \mathrm{Cl}_{2} / \mathrm{CH}_{3} \mathrm{OH}$ (1:1) as the eluent. Initially $100 \mathrm{~mL}$ was collected into a conical flask and discarded, then twenty-five fractions $(25 \times 10 \mathrm{~mL})$ were collected. Fractions 9 and 10 afforded jaceosidin $(\mathbf{5}, 9 \mathrm{mg}, 0.088 \%$ dry wt).

\subsubsection{3-Acetoxy-7,8-dihydroxyserrulat-14-en-19-oic acid (1)}


Stable brown gum; $[\alpha]_{\mathrm{D}}^{25}+6.0\left(c 0.033, \mathrm{CH}_{3} \mathrm{OH}\right) ; \mathrm{UV}\left(\mathrm{CH}_{3} \mathrm{OH}\right) \lambda_{\max } \mathrm{nm}(\log$ ع) 215 (4.28), 257 (3.75), 320 (3.27); IR $v_{\max }$ (KBr) 3262 (br), 2961, 2928, 2874, 2565, 1731, 1667, 1618, 1481, 1434, 1371, 1291, 1245, 1026, $999 \mathrm{~cm}^{-1} ;{ }^{1} \mathrm{H}$ and ${ }^{13} \mathrm{C}$ NMR data (DMSO- $d_{6}$ ) see Tables 1 and 2; (-)-LRESIMS m/z (rel. int.) 389 (100) [M H] ; (+)-LRESIMS $m / z$ (rel. int.) 413 (100) $\left[\mathrm{M}+\mathrm{Na}^{+}\right.$; (+)-HRESIMS $m / z 413.1955$ $\left(\mathrm{C}_{22} \mathrm{H}_{30} \mathrm{O}_{6} \mathrm{Na}[\mathrm{M}+\mathrm{Na}]^{+}\right.$requires 413.1935$)$.

\subsubsection{3,7,8-Trihydroxyserrulat-14-en-19-oic acid (2)}

Stable brown gum; $[\alpha]_{\mathrm{D}}^{25}+9.1\left(c 0.044, \mathrm{CH}_{3} \mathrm{OH}\right) ; \mathrm{UV}\left(\mathrm{CH}_{3} \mathrm{OH}\right) \lambda_{\max } \mathrm{nm}(\log$ ع) 216 (4.35), 225 (4.26), 259 (3.91), 325 (3.38); IR $v_{\max }(\mathrm{KBr}) 3267$ (br), 2960, 2929, 2558, 1664, 1614, 1512, 1433, 1377, 1292, 1219, 1025, $998 \mathrm{~cm}^{-1} ;{ }^{1} \mathrm{H}$ and ${ }^{13} \mathrm{C} \mathrm{NMR}$ data (DMSO- $d_{6}$ ) see Tables 1 and 2; (-)-LRESIMS m/z (rel. int.) 347 (100) [M - H]'; (+)-HRESIMS $m / z$ 371.1844 $\left(\mathrm{C}_{20} \mathrm{H}_{28} \mathrm{O}_{5} \mathrm{Na}[\mathrm{M}+\mathrm{Na}]^{+}\right.$requires 371.1829$)$.

\subsubsection{3,19-Diacetoxy-8-hydroxyserrulat-14-ene (3)}

Stable brown gum; $[\alpha]_{\mathrm{D}}{ }^{25}+5.5\left(c 0.037, \mathrm{CH}_{3} \mathrm{OH}\right) ; \mathrm{UV}\left(\mathrm{CH}_{3} \mathrm{OH}\right) \lambda_{\max } \mathrm{nm}(\log$ ع) 207 (3.83), 227 (3.42), 260 (2.94), 287 (2.62), 324 (2.45); IR $v_{\max }$ (KBr) 3262 (br), 2960, 2931, 2360, 2342, 1733, 1668, 1618, 1586, 1456, 1433, 1374, 1292, 1243, 1026, $1003 \mathrm{~cm}^{-1}$; ${ }^{1} \mathrm{H}$ and ${ }^{13} \mathrm{C}$ NMR data (DMSO- $d_{6}$ ) see Tables 1 and 2; (-)-LRESIMS $m / z$ (rel. int.) $401(100)[\mathrm{M}-\mathrm{H}]^{-}$; (+)-LRESIMS $m / z$ (rel. int.) $425(100)[\mathrm{M}+\mathrm{Na}]^{+}$; (+)-HRESIMS $m / z, 425.2319\left(\mathrm{C}_{24} \mathrm{H}_{34} \mathrm{O}_{5} \mathrm{Na}[\mathrm{M}+\mathrm{Na}]^{+}\right.$requires 425.2298).

\subsubsection{Identification of known compounds}

Compounds 4 and 5 were identified as the previously reported natural products verbascoside (Aligiannis et al., 2003; Andary et al., 1982) and jaceosidin 
(ApSimon et al., 1963; Nakasugi et al., 2000) following 1D/2D NMR $\left({ }^{1} \mathrm{H},{ }^{13} \mathrm{C}\right.$, gCOSY, gHSQC, gHMBC, ROESY) and MS data analysis and comparison with literature values. The optical rotation value obtained for $4\left([\alpha]_{\mathrm{D}}{ }^{27}-68.0[c 0.05\right.$, $\left.\mathrm{CH}_{3} \mathrm{OH}\right]$ ) was in agreement with literature data (Aligiannis et al., 2003; Andary et al., 1982).

\subsection{Acetylation of 2}

Serrulatane $2(23.9 \mathrm{mg}, 0.0687 \mathrm{mmol})$ was dissolved in $\mathrm{Ac}_{2} \mathrm{O}(1 \mathrm{~mL})$ and dry pyridine (1 mL) and stirred at rt overnight (Davis et al., 1999). The solution was dried under $\mathrm{N}_{2}$ and the resulting product pre-adsorbed to $\mathrm{C}_{18}$-bonded silica $(\sim 1 \mathrm{~g})$, packed into a guard cartridge, and subjected to semi-preparative HPLC using a $\mathrm{C}_{18}$-bonded silica column. Isocratic conditions of $\mathrm{H}_{2} \mathrm{O} / \mathrm{CH}_{3} \mathrm{OH}$ (9:1) were held for $10 \mathrm{~min}$, followed by a linear gradient to $\mathrm{CH}_{3} \mathrm{OH}$ over $40 \mathrm{~min}$, then isocratic conditions of $\mathrm{CH}_{3} \mathrm{OH}$ for $10 \mathrm{~min}$ all at a flow rate of $9 \mathrm{~mL} / \mathrm{min}$. Sixty fractions $(60 \times 1 \mathrm{~min})$ were collected. 3,8-Diacetoxy-7-hydroxyserrulat-14-en-19-oic acid (6, $16 \mathrm{mg}, 53 \%)$ eluted in fractions $40-43$.

\subsubsection{3,8-Diacetoxy-7-hydroxyserrulat-14-en-19-oic acid (6)}

Stable opaque gum; $[\alpha]_{\mathrm{D}}^{26}+17.2\left(c 0.07, \mathrm{CH}_{3} \mathrm{OH}\right) ; \mathrm{UV}\left(\mathrm{CH}_{3} \mathrm{OH}\right) \lambda_{\max } \mathrm{nm}(\log$ ع) 211 (3.64), 246 (2.94), 309 (2.59); ${ }^{1} \mathrm{H}$ NMR (600 MHz, DMSO- $\left.d_{6}\right) \delta_{\mathrm{H}} 0.44(3 \mathrm{H}, \mathrm{d}$, $J=6.6 \mathrm{~Hz}, \mathrm{H}-18), 1.14(3 \mathrm{H}, \mathrm{d}, J=6.6 \mathrm{~Hz}, \mathrm{H}-20), 1.23(1 \mathrm{H}, \mathrm{ddt}, J=13.2,6.6,6.0 \mathrm{~Hz}$, H-12), 1.39 (1H, ddt, $J=13.2,7.2,6.0 \mathrm{~Hz}, \mathrm{H}-12), 1.56(1 \mathrm{H}, \mathrm{m}, \mathrm{H}-2 \beta), 1.57$ (3H, s, H17), 1.65 (3H, s, H-16), 1.93 (1H, m, H-11), 1.96 (2H, brd, $J=6.6 \mathrm{~Hz}, \mathrm{H}-13), 2.00$ (3H, s, H-22), 2.03 (1H, m, H-2 2 ), 2.22 (3H, s, H-24), 2.94 (1H, d, brd, $J=3.0 \mathrm{~Hz}, \mathrm{H}-$ 
4), $3.01(1 \mathrm{H}, \mathrm{qd}, J=6.6,6.0 \mathrm{~Hz}, \mathrm{H}-1), 5.11(1 \mathrm{H}, \mathrm{t}, J=7.8 \mathrm{~Hz}, \mathrm{H}-14), 5.18$ (1H, ddd, $J$ $=12.0,4.8,3.0 \mathrm{~Hz}, \mathrm{H}-3), 7.24(1 \mathrm{H}, \mathrm{s}, \mathrm{H}-5) ;{ }^{13} \mathrm{C}$ NMR $\left(125 \mathrm{MHz}, \mathrm{DMSO}-d_{6}\right) \delta_{\mathrm{C}} 17.5$ (C-17), 18.9 (C-18), 20.4 (C-24), 21.0 (C-22), 22.5 (C-20), 25.4 (C-13), 25.5 (C-16), 28.3 (C-1), 31.3 (C-2), 31.4 (C-11), 37.9 (C-12), 44.4 (C-4), 69.7 (C-3), 109.5 (C-6), 122.4 (C-10), 124.4 (C-14), 127.0 (C-5), 130.7 (C-15), 136.1 (C-9), 136.5 (C-8), 153.4 (C-7), 168.1 (C-23), 169.7 (C-21), 171.0 (C-19); (-)-LRESIMS m/z (rel. int.) 431 (100) $[\mathrm{M}-\mathrm{H}]^{-}$; (-)-HRESIMS m/z $431.2077\left(\mathrm{C}_{24} \mathrm{H}_{31} \mathrm{O}_{7}[\mathrm{M}-\mathrm{H}]^{-}\right.$requires 431.2075).

\subsection{Methylation of 2}

Serrulatane 2 (23.9 mg, $0.0687 \mathrm{mmol})$ was dissolved in $\mathrm{CH}_{3} \mathrm{OH}: \mathrm{CH}_{2} \mathrm{Cl}_{2}(1: 1$, $2 \mathrm{~mL}$ ) before TMS-diazomethane (2.0 M in diethyl ether, $172 \mu \mathrm{L}, 0.3435 \mathrm{mmol})$ was added dropwise (Garfunkle et al., 2009). The reaction was stirred for $20 \mathrm{~min}$ at $\mathrm{rt}$ then quenched with $\mathrm{AcOH}(50 \mu \mathrm{L})$. The solvent was removed under $\mathrm{N}_{2}$ and the resulting product pre-adsorbed to $\mathrm{C}_{18}$-bonded silica ( $1 \mathrm{~g}$ ), packed into a guard cartridge, and subjected to semi-preparative HPLC using a $\mathrm{C}_{18}$-bonded silica column. Isocratic conditions of $\mathrm{H}_{2} \mathrm{O} / \mathrm{CH}_{3} \mathrm{OH}(9: 1)$ were held for 10 min, followed by a linear gradient to $\mathrm{CH}_{3} \mathrm{OH}$ over $40 \mathrm{~min}$, then isocratic conditions of $\mathrm{CH}_{3} \mathrm{OH}$ for $10 \mathrm{~min}$ all at a flow rate of $9 \mathrm{~mL} / \mathrm{min}$. Sixty fractions $(60 \times 1 \mathrm{~min})$ were collected. $3,7,8-$ Trihydroxyserrulat-14-en-methyl-19-benzoate $(7,9 \mathrm{mg}, 35 \%)$ eluted in fractions 5051.

4.5.1. 3,7,8-Trihydroxyserrulat-14-en-methyl-19-benzoate (7) 
Stable brown gum; $[\alpha]_{\mathrm{D}}^{25}+3.2\left(c 0.063, \mathrm{CH}_{3} \mathrm{OH}\right) ; \mathrm{UV}\left(\mathrm{CH}_{3} \mathrm{OH}\right) \lambda_{\max } \mathrm{nm}(\log$ ع) 217 (4.39), 227 (4.33), 262 (4.06), 328 (3.48); ${ }^{1} \mathrm{H}$ NMR (600 MHz, DMSO- $\left.d_{6}\right) \delta_{\mathrm{H}}$ $0.36(3 \mathrm{H}, \mathrm{d}, J=7.2 \mathrm{~Hz}, \mathrm{H}-18), 1.17(3 \mathrm{H}, \mathrm{d}, J=6.6 \mathrm{~Hz}, \mathrm{H}-20), 1.25(1 \mathrm{H}, \mathrm{m}, \mathrm{H}-12)$, $1.45(1 \mathrm{H}, \mathrm{brd}, J=12.6 \mathrm{~Hz}, \mathrm{H}-2 \beta), 1.46(1 \mathrm{H}, \mathrm{m}, \mathrm{H}-12) 1.57$ (3H, s, H-17), 1.65 (3H, s, H-16), 1.87 (1H, ddd, $J=12.6,12.0,6.0 \mathrm{~Hz}, \mathrm{H}-2 \alpha), 1.97$ (2H, ddd, $J=7.8,7.2,7.2$ Hz, H-13), 2.11 (1H, brq, $J=7.2 \mathrm{~Hz}, \mathrm{H}-11), 2.70(1 \mathrm{H}$, brd, $J=3.6 \mathrm{~Hz}, \mathrm{H}-4), 3.20$ (1H, qd, $J=6.6,6.0 \mathrm{~Hz}, \mathrm{H}-1), 3.87$ (3H, s, H-21), 4.05 (1H, brdddd, $J=12.0,4.2,3.6$, $3.0 \mathrm{~Hz}, \mathrm{H}-3), 4.65$ (1H, brd, $J=3.0 \mathrm{~Hz}, 3-\mathrm{OH}), 5.13(1 \mathrm{H}, \mathrm{t}, J=7.2 \mathrm{~Hz}, \mathrm{H}-14), 6.95$ $(1 \mathrm{H}, \mathrm{s}, \mathrm{H}-5) ;{ }^{13} \mathrm{C}$ NMR $\left(125 \mathrm{MHz}, \mathrm{DMSO}-d_{6}\right) \delta_{\mathrm{C}} 17.5(\mathrm{C}-17), 18.8(\mathrm{C}-18), 21.8(\mathrm{C}-$ 20), 25.5 (C-13), 25.7 (C-16), 28.5 (C-1), 29.9 (C-11), 34.5 (C-2), 38.5 (C-12), 48.1 (C-4), 52.3 (C-21), 64.8 (C-3), 109.6 (C-6), 119.5 (C-5), 124.7 (C-14), 128.9 (C-10), 130.2 (C-15), 135.8 (C-9), 142.6 (C-8), 146.5 (C-7), 170.0 (C-19); (+)-LRESIMS m/z (rel. int.) $363(100)[\mathrm{M}+\mathrm{H}]^{+}$; (-)-HRESIMS m/z $361.2018\left(\mathrm{C}_{21} \mathrm{H}_{29} \mathrm{O}_{5}[\mathrm{M}-\mathrm{H}]^{-}\right.$ requires 361.2020).

4.6. Bacterial strains and control values

Compounds 1-7 were screened against one Gram-negative bacterial strain: Escherichia coli (ATCC 25922), and nine Gram-positive bacterial strains: Enterococcus faecalis (VanA clinical isolate), Enterococcus faecium (MDR Van A ATCC 51559), Streptococcus pyogenes (Group A ATCC 12344), Streptococcus pneumoniae (MDR ATCC 700677), Staphylococcus aureus (mMRSA clinical isolate), Staphylococcus aureus (MRSA ATCC 43300), Staphylococcus aureus (GISA NRS 17), Staphylococcus aureus (GISA NRS 1), and Staphylococcus aureus (MRSA DapRSA clinical isolate). The experiments were all performed in duplicate (n 
=2) with vancomycin, colistin, and daptomycin used as positive controls. Control MIC values for vancomycin were as follows: E. faecalis $(>64 \mu \mathrm{g} / \mathrm{mL})$, E. faecium (> $64 \mu \mathrm{g} / \mathrm{mL})$, S. pyogenes $(0.5 \mu \mathrm{g} / \mathrm{mL})$, S. pneumoniae $(1 \mu \mathrm{g} / \mathrm{mL})$, and $S$. aureus strains (1-4 $\mu \mathrm{g} / \mathrm{mL})$. The control MIC value for colistin was as follows: E. coli $(\leq 0.03$ $\mu \mathrm{g} / \mathrm{mL})$. Control MIC values for daptomycin were as follows: E. coli (> $64 \mu \mathrm{g} / \mathrm{mL})$, E. faecalis $(16 \mu \mathrm{g} / \mathrm{mL})$, E. faecium $(16 \mu \mathrm{g} / \mathrm{mL}), S$. pyogenes $(0.25 \mu \mathrm{g} / \mathrm{mL}), S$. pneumoniae $(4 \mu \mathrm{g} / \mathrm{mL})$, and $S$. aureus strains $(2-16 \mu \mathrm{g} / \mathrm{mL})$. Positive growth control rows of bacteria and DMSO + bacteria as well as a negative control row of only media were included for every plate tested.

\subsubsection{MIC assay}

MICs were determined by a two-fold serial broth microdilution according to the recommendation of CLSI standards with an inoculum of $5 \times 10^{5} \mathrm{cfu} / \mathrm{mL}$. The compounds along with standard antibiotics were serially diluted twofold across the wells of 96-well non-binding surface plates (NBS, Corning). Standards ranged from $64-0.03 \mu \mathrm{g} / \mathrm{mL}$, and the compounds from $128-0.06 \mu \mathrm{g} / \mathrm{mL}$ with final volumes of $50 \mu \mathrm{L}$ per well. Gram-positive and Gram-negative bacteria were cultured in Mueller Hinton broth (MHB) (Bacto laboratories, Cat. no. 211443) at $37{ }^{\circ} \mathrm{C}$ overnight. A sample of each culture was then diluted 40-fold in fresh MHB broth and incubated at $37{ }^{\circ} \mathrm{C}$ for $2-3 \mathrm{~h}$. The resultant mid-log phase cultures were diluted to the final concentration of $5 \times 10^{5} \mathrm{cfu} / \mathrm{mL}$, then $50 \mu \mathrm{L}$ was added to each well of the compound containing 96-well plates. All the plates were covered and incubated at $37^{\circ} \mathrm{C}$ for $24 \mathrm{~h}$. MICs were the lowest concentration showing no visible growth. 
Resazurin $(30 \mu \mathrm{L}, 0.01 \%)$ was added to each well of the 96-well plates after the MIC values were determined. The compounds were then incubated at $37{ }^{\circ} \mathrm{C}$ for a further 18 to $24 \mathrm{~h}$. Wells with blue coloration indicated dead microorganisms, whereas wells with pink coloration indicated live microorganisms. The MBC value was determined by the lowest concentrations of the wells with blue coloration.

\section{Acknowledgements}

J. Glazebrook from the Society for Growing Australian Plants (SGAP) is acknowledged for the plant collection and identification. We thank R. Quinn from Griffith University for access to the Eremophila samples, which form part of the Eskitis Institute's Nature Bank biota library. The Australian Research Council is acknowledged for support towards the NMR and MS equipment (LE0668477 and LE0237908). We thank H. Vu from Griffith University and G. MacFarlane of the University of Queensland for acquiring the HRESIMS measurements. The bacterial GISA isolates were obtained through the Network on Antimicrobial Resistance in Staphylococcus aureus (NARSA) program: supported under NIAID, NIH Contract HHSN272200700055C, while the clinical isolates were supplied by D. Paterson of the University of Queensland Centre for Clinical Research. ECB thanks the Australian Government for an APA scholarship.

\section{Appendix A. Supplementary data}


Supplementary data associated with this article can be found, in the online version, at http://...

\section{Figure Legends}

Fig. 1. Chemical structures for the isolated natural products $\mathbf{1 - 5}$, the semi-synthetic derivatives 6 and 7, and related serrulatane natural products 8-15

Fig. 2. Key COSY and HMBC correlations for $\mathbf{1}$

\section{Table Legends}

Table 1. ${ }^{1} \mathrm{H}$ NMR data for serrulatanes $1-3^{\mathrm{a}}$

Table 2. ${ }^{13} \mathrm{C}$ NMR data for serrulatanes $1-3^{\mathrm{a}}$

Table 3. Antibacterial activity of compounds 1-7

\section{References}

Aligiannis, N., Mitaku, S., Tsitsa-Tsardis, E., Harvala, C., Tsaknis, I., Lalas, S., Haroutounian, S., 2003. Methanolic extract of Verbascum macrurum as a source of natural preservatives against oxidative rancidity. J. Agric. Food Chem. 51, 7308-7312. Anakok, O. F., Ndi, C. P., Barton, M. D., Griesser, H. J., Semple, S. J., 2011. Antibacterial spectrum and cytotoxic activities of serrulatane compounds from the Australian medicinal plant Eremophila neglecta. J. Appl. Microbiol. 112, 197-204. Andary, C., Wylde, R., Laffite, C., Privat, G., Winternitz, F., 1982. Structures of verbascoside and orobanchoside, caffeic acid sugar esters from Orobanche rapumgenistae. Phytochemistry (Elsevier) 21, 1123-1127.

ApSimon, J. W., Haynes, N. B., Sim, K. Y., Whalley, W. B., 1963. 5,7,4'-Trihydroxy3',6-dimethoxyflavone, a pigment from Digitalis lanata L. J. Chem. Soc., 3780-3782. Barnes, E. C., Carroll, A. R., Davis, R. A., 2011. Mitchellenes A-E, cyclic sesquiterpenes from the Australian plant Eremophila mitchellii. J. Nat. Prod. 74, 1888-1893.

Barnes, E. C., Choomuenwai, V., Andrews, K. T., Quinn, R. J., Davis, R. A., 2012. Design and synthesis of screening libraries based on the muurolane natural product scaffold. Org. Biomol. Chem. 10, 4015-4023. 
Beattie, K., 2009. Phytochemical studies and bioactivity of Centipeda and Eremophila species. PhD Thesis, Southern Cross University, Lismore.

Beattie, K. D., Waterman, P. G., Forster, P. I., Thompson, D. R., Leach, D. N., 2011.

Chemical composition and cytotoxicity of oils and eremophilanes derived from various parts of Eremophila mitchellii Benth. (Myoporaceae) Phytochemistry (Elsevier) 72, 400-408.

Chinnock, R. J., 2007. Eremophila and allied genera. Rosenberg Publishing, Dural, NSW.

Croft, K. D., Ghisalberti, E. L., Jefferies, P. R., Proudfoot, G. M., 1981. The chemistry of Eremophila spp. XVI. New serrulatanes from Eremophila spp. Aust. J. Chem. 34, 1951-1957.

Croft, K. D., Ghisalberti, E. L., Jefferies, P. R., Raston, C. L., White, A. H., Hall, S. R., 1977. The chemistry of Eremophila spp. VI. Stereochemistry and crystal structure of dihydroxyserrulatic acid. Tetrahedron 33, 1475-1480.

Davis, R. A., Carroll, A. R., Pierens, G. K., Quinn, R. J., 1999. New lamellarin alkaloids from the Australian ascidian, Didemnum chartaceum. J. Nat. Prod. 62, 419424.

Dictionary of Natural Products, 2012. DVD version 20.2, Chapman and Hall, London. Forster, P. G., Ghisalberti, E. L., Jefferies, P. R., Poletti, V. M., Whiteside, N. J., 1986. Serrulatane diterpenes from Eremophila spp. Phytochemistry (Elsevier) 25, 1377-1383.

Garfunkle, J., Kimball, F. S., Trzupek, J. D., Takizawa, S., Shimamura, H., Tomishima, M., Boger, D. L., 2009. Total synthesis of chloropeptin II (complestatin) and chloropeptin I. J. Am. Chem. Soc. 131, 16036-16038.

Ghisalberti, E. L., 1994a. The ethnopharmacology and phytochemistry of Eremophila species (Myoporaceae). J. Ethnopharmacol. 44, 1-9.

Ghisalberti, E. L., 1994b. The phytochemistry of the Myoporaceae. Phytochemistry (Elsevier) 35, 7-33.

Grice, I. D., Garhnam, B., Pierens, G., Rogers, K., Tindal, D., Griffiths, L. R., 2003. Isolation of two phenylethanoid glycosides from Eremophila gilesii. J.

Ethnopharmacol. 86, 123-125.

Latz, P., 1995. Bushfires and bushtucker: Aboriginal plant use in central Australia. IAD Press, Alice Springs, NT.

Liu, Q., Harrington, D., Kohen, J. L., Vemulpad, S., Jamie, J. F., 2006. Bactericidal and cyclooxygenase inhibitory diterpenes from Eremophila sturtii. Phytochemistry (Elsevier) 67, 1256-1261.

Low, T., 1990. Bush medicine: a pharmacopoeia of natural remedies Collins/Angus \& Robertson Publishers, North Ryde, Australia.

Nakasugi, T., Nakashima, M., Komai, K., 2000. Antimutagens in Gaiyou (Artemisia argyi Levl. et Vant.). J. Agric. Food Chem. 48, 3256-3266.

Nature Bank, 2011. Eskitis Institute, Griffith University, http: //www. naturebank.com.au/.

Ndi, C. P., Semple, S. J., Griesser, H. J., 2012. Instability of antibacterial serrulatane compounds from the Australian plant species Eremophila duttonii. Aust. J. Chem. 65, 20-27.

Ndi, C. P., Semple, S. J., Griesser, H. J., Barton, M. D., 2007a. Antimicrobial activity of some Australian plant species from the genus Eremophila. J. Basic Microbiol. 47, 158-164. 
Ndi, C. P., Semple, S. J., Griesser, H. J., Pyke, S. M., Barton, M. D., $2007 b$.

Antimicrobial compounds from Eremophila serrulata. Phytochemistry (Elsevier) 68, 2684-2690.

Ndi, C. P., Semple, S. J., Griesser, H. J., Pyke, S. M., Barton, M. D., 2007c. Antimicrobial compounds from the Australian desert plant Eremophila neglecta. J. Nat. Prod. 70, 1439-1443.

Palombo, E. A., Semple, S. J., 2001. Antibacterial activity of traditional Australian medicinal plants. J. Ethnopharmacol. 77, 151-157.

Palombo, E. A., Semple, S. J., 2002. Antibacterial activity of Australian plant extracts against methicillin-resistant Staphylococcus aureus (MRSA) and vancomycinresistant enterococci (VRE). J. Basic Microbiol. 42, 444-448.

Pennacchio, M., Alexander, E., Ghisalberti, E. L., Richmond, G. S., 1995.

Cardioactive effects of Eremophila alternifolia extracts. J. Ethnopharmacol. 47, 9195.

Pennacchio, M., Kemp, A. S., Taylor, R. P., Wickens, K. M., Kienow, L., 2005.

Interesting biological activities from plants traditionally used by Native Australians. J. Ethnopharmacol. 96, 597-601.

Pennacchio, M., Syah, Y. M., Ghisalberti, E. L., Alexander, E., 1996. Cardioactive compounds from Eremophila species. J. Ethnopharmacol. 53, 21-27.

Pennacchio, M., Syah, Y. M., Ghisalberti, E. L., Alexander, E., 1997. Cardioactive iridoid glycosides from Eremophila species. Phytomedicine 4, 325-330.

Pretsch, E., Buhlmann, P., Badertscher, M., 2009. Structure determination of organic compounds. Springer, Berlin.

Rogers, K. L., Fong, W. F., Redburn, J., Griffiths, L. R., 2002. Fluorescence detection of plant extracts that affect neuronal voltage-gated $\mathrm{Ca}^{2+}$ channels. Eur. J. Pharm. Sci. 15, 321-330.

Rogers, K. L., Grice, I. D., Griffiths, L. R., 2000. Inhibition of platelet aggregation and 5-HT release by extracts of Australian plants used traditionally as headache treatments. Eur. J. Pharm. Sci. 9, 355-363.

Rogers, K. L., Grice, I. D., Griffiths, L. R., 2001. Modulation of in vitro platelet 5-HT release by species of Erythrina and Cymbopogon. Life Sci. 69, 1817-1829.

SciFinder, 2012. American Chemical Society, https: //scifinder.cas.org. Semple, S. J., Reynolds, G. D., O'Leary, M. C., Flower, R. L. P., 1998. Screening of Australian medicinal plants for antiviral activity. J. Ethnopharmacol. 60, 163-172. Smith, J. E., Tucker, D., Watson, K., Jones, G. L., 2007. Identification of antibacterial constituents from the indigenous Australian medicinal plant Eremophila duttonii F. Muell. (Myoporaceae). J. Ethnopharmacol. 112, 386-393.

Syah, Y. M., Ghisalberti, E. L., 1997. Serrulatane diterpenes from a new Eremophila species. Phytochemistry (Elsevier) 45, 1479-1482.

Tippett, L. M., Massy-Westropp, R. A., 1993. Serrulatane diterpenes from Eremophila duttonii. Phytochemistry (Elsevier) 33, 417-421.

Wilkinson, J. M., Cavanagh, H. M. A., 2005. Antibacterial activity of essential oils from Australian native plants. Phytother. Res. 19, 643-646. 